\title{
EL CUADERNO COLECTIVO DE MAYRA BARRAZA: ESPEJO DE UNA OBRA EN SINGULAR
}

\author{
POR \\ Tania Pleitez Vela \\ Universitat Autònoma de Barcelona
}

\section{ESCENARIOS AUTORIALES EN FEMENINO}

Comienzo este artículo enunciando una serie de interrogantes: ¿Cómo son los escenarios que una autora elige para cincelarse en el campo artístico? ¿Dónde se encuentra la división entre el sujeto íntimo y la máscara ficcional o, mejor dicho, la diferencia entre la verdad subjetiva y la verdad artística, la producida por el personaje que se otorga un lugar -intelectual, creativo, afectivo- tanto en el espacio cultural (público) como en el texto? ¿Existe realmente la autonomía de la obra frente a lo biográfico? ¿Es la autora un sujeto previo a su producción, es decir, una creadora autónoma e incluso solitaria?

Octavio Paz propuso que siempre se percibirá un vacío, una tierra de nadie, que no podremos identificar con exactitud debido precisamente a la complejidad de este proceso; y así lo resume en su famoso ensayo sobre sor Juana Inés de la Cruz: "La vida no explica enteramente la obra y la obra tampoco explica la vida. Entre una y otra hay una zona vacía, una hendidura. Hay algo que está en la obra y no en la vida del autor; ese algo se llama creación o invención artística y literaria. El poeta, el escritor es el olmo que sí da peras" (13). Si seguimos a Paz, resultaría arriesgado señalar la división entre la verdad literaria y la verdad subjetiva como algo que no sea "una tierra de nadie". Sin embargo, la más reciente teoría autorial se arriesga y lo nombra, aunque no como una hendidura o un vacío, sino todo lo contrario. Se trataría, más bien, de una construcción, aparentemente invisible, pero anegada de una serie de determinantes, como todo constructo, planteándose así esta problemática desde un paradigma que ya Paul de Man había señalado en 1979: "nuestro tema se ocupa del conferir y el despojar de máscaras, del otorgar y deformar rostros, de figuras, de figuración y de desfiguración" (116). Lo anterior sirve para intentar responder a una pregunta clave en el tema que nos ocupa: ¿cómo se agencia la subjetividad de autor/a dentro de la maquinaria cultural?

Pérez Fontdevila y Torras destacan lo enunciado por dos reconocidos teóricos de la autoría. Por un lado, José-Luis Diaz, autor del ya paradigmático L 'éscrivain imaginaire 
(2007), quien afirma que la recepción de la figura autorial viene a ser "el resultado aleatorio de un juego de construcción", una especie de "mecano" o "puzle" por el que se filtra un "autor de síntesis" (en Pérez Fontdevila y Torras 44); y por el otro, Eleonora Cróquer, quien sostiene que ese autor no señala, precisamente, a un sujeto real sino que más bien compone un artefacto cultural (ibid.). Pareciera entonces, que hay dos tipos de engendramientos: el que tiene lugar cuando el autor se crea a sí mismo por medio de su arte (un autoengendramiento que en realidad representa su exceso de autor, ya que es así como se quiere presentar); y el que sucede en la comunidad, la cual debe validar y reconocer, o contrafirmar, a ese autor como tal; o, mejor dicho, su imagen autorial edificada, al mismo tiempo recreada e interpretada por dicha recepción. En esa dialéctica, el autor se mantiene en una especie de cuerda floja, entre su juego de construcción y el crédito que le otorga la comunidad (Pérez Fontdevila y Torras 17).

La figura de autor/a, por lo tanto, inevitablemente entra en escena, utiliza dispositivos mediáticos donde incluso aquel/la que los rechaza, o decide desertar del foco, está adoptando una postura: "si rehúso la Imagen, produzco la imagen de aquel que rehúsa las Imágenes", indujo Barthes (305-306). A propósito, Alain Viala especifica la noción de postura y la iguala a las maneras de "asumir y ocupar una posición"; se trata, pues, de la "propiedad de distinguirse" (ya sea adoptando diversas posturas a lo largo del tiempo o manteniendo una sola postura continuada). Lo anterior, según Viala, responde a la lógica de una estrategia, sea esta literaria o artística (citado en Meizoz 188). Este ethos autorial, agrega Meizoz, no solo nos permite identificar las estrategias de autor/a en el campo cultural sino que también sus elecciones formales, su poética. Por lo tanto, este estudioso incluye tanto la "dimensión retórica (textual) como la dimensión comportamental (contextual)": lugar de enunciación que sintetiza la conducta y el discurso, la historia y el lenguaje, y en el que postura no equivale a pose, no se reduce a un artificio (aunque en ocasiones sí lo sea), ni tiene una connotación peyorativa (Meizoz 188-89, 191 y 193).

Se propone, entonces, que los/as autores/as encarnan personajes que sacan a escena, pero esos personaje y sus correspondientes escenarios han sido edificados en diálogo no solo con un yo íntimo, sino también con una comunidad y una cultura que en diferentes momentos de la historia han alimentado la función del sujeto autorial. Así, ese sujeto literario o artístico ha asimilado su posición, ya sea como singular, solitario, original, único, maldito, comprometido, etc. En otras palabras, la figura de autor/a responde tanto a un talento y afán expresivo, como a la imagen que quiere fijar dentro de la realidad y/o campo en que se encuentra insertado. Se forja, pues, un tejido discursivo estratégico, tanto en el plano interno (autorrepresentación en y a través de su obra), como externo (en tanto adopta la función autorial en los medios de comunicación, discursos públicos, noticias biográficas, paratextos, etc.). Los autores, por lo tanto, juegan con o se rebelan contra la imagen de poeta, escritor o artista que se ha diseminado y tallado en la tradición -imagen donde también caben categorías de

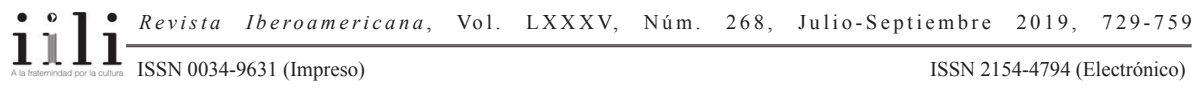


género, raza, etc.-. En ese sentido, resulta apropiado citar las palabras de Rodríguez Gutiérrez, en referencia a las poetas mujeres, cuando afirma que en la obra de estas se perfila "el personaje para el cual el verso, la poesía, es un escenario; un escenario donde gritar -y producir- verdades" (132). Precisamente, esta estudiosa opina que el elemento dramático presente en varios poemas escritos por mujeres aparece relacionado al sentido del personaje teatral y, en estos, el drama se presenta como valor y estrategia: “Alfonsina [Storni] escribe un 'diario poético', pero ese 'diario poético' es también 'teatral'; en él lo público, el drama femenino (y entiéndase aquí drama en su doble sentido), se disfraza de privado para poder ser escuchado. Solo así, en el registro poético, -y por lo tanto entendido como íntimo, personal, privado- iba a ser escuchado este discurso" (135-136; cursivas del original).

Pongamos otro ejemplo. La argentina Alejandra Pizarnik, en "Solo un nombre", dice: "alejandra alejandra / debajo estoy yo / alejandra" (65). Pizarnik parece aceptar el desdoblamiento entre el sujeto y el personaje al hablarnos de Alejandra, debajo de la cual está yo, también de nombre Alejandra. Así, el nombre equivale a la máscara de identidad (personaje, verdad literaria), mientras que yo se identifica con intimidad (verdad subjetiva y casi incomunicable). Pero, ¿quién escribe el poema? ¿Cuáles son los recursos (retóricos, estéticos) que le permiten a ese yo apropiarse de un personaje poético que lo represente (hable de sí y de su espacio vivencial) en el contexto del poema configurado también como escenario? Precisamente, César Aira, en su ensayo sobre la argentina, señala la presencia de un personaje pizarnikiano, uno que la poeta saca a escena por medio de una serie de metáforas que le permiten a Alejandra (sujeto que se constituye en su dislocación) "seguir escribiendo"; es decir, esta especie de fórmula metafórica viene a ser "su parodia o su reducción al absurdo", cuyo cometido es "subjetivizar la escritura automática, y mantener la máquina en movimiento" (17). Aira ironiza al respecto cuando subraya que este personaje se ha confundido con la vida de la argentina, incluso cuando ella aún vivía:

Es como si toda la gente que la conoció se sintiera irresistiblemente llevada a competir con ella en imágenes cultas y elegantes, y terminan diciendo siempre lo mismo: su cuarto era el "barco ebrio", su presencia la de "la náufraga deshabitada de sí misma", la mirada de sus "grandes ojos verdes" tenía el "asombro maravillado de la niña en un jardín”, en sus desplazamientos nunca falta la "maleta de piel de pájaro", etc. La quincalla poética que ella misma usó con encomiable economía y trasmutó en hermosos poemas, la rodeaba como una malla infranqueable. (48)

Sin embargo, esa "malla infranqueable" -analogía que a mi parecer es trascendida por el aparato teórico que nos ocupa- en realidad viene a ser un resquicio por donde se cuela una figura de autora cincelada, simultáneamente afirmada y certificada por una comunidad. Precisamente, Pérez Fontdevila, Torras y Cróquer sostienen que 
la sociocrítica, la sociología de la literatura o las teorías del análisis del discurso mediante las propuestas de los ya mencionados José-Luis Diaz y Jérôme Meizoz, y también Dominique Maingueneau- nos avisan de que la figura de autor/a ha dejado de aparecer como "un sujeto previo a su producción", es decir, se manifiesta como "un producto cuyo origen ya no es una instancia solitaria y autónoma sino el colectivo de agentes que participan de la cultura entendida como institución y mercado, incluyendo sus receptores o consumidores" (23). Ahora bien, ¿cuáles han sido las estrategias de las mujeres para decir(se) y otorgase espacios, para ser, habitar, hacer arte, discurso y política, y trascender lo que la tradición le adjudica? Si las poetas tradicionalmente establecieron un escenario-texto desde donde "gritar -y producir- verdades" -como afirma Rodríguez Gutiérrez-, no resultaría descabellado afirmar que las artistas visuales también han recurrido a esta estrategia escénica-textual.

Con todo lo anterior en mente, en este artículo examinaré los escenarios por los que se mueve y desdobla la figura de autora de la artista salvadoreña Mayra Barraza (1966). Se indagará en su bitácora personal 100 días en la República de la Muerte (2006), una especie de diario íntimo y al mismo tiempo colectivo, por medio del cual se interrogó a la cultura de la violencia que vivía El Salvador a mediados de los años 2000 -violencia que se ha extendido y agravado hasta ahora-. Es a partir de esa bitácora que la artista trenza una serie de trabajos artísticos reunidos bajo el título República de la Muerte (2006-2009). Para el desglose de ese personaje artístico, se recurrirá a paratextos y perfiles, así como a entrevistas y retratos de Barraza. Sin embargo, con el fin de comprender mejor la recreación de estos escenarios barrazaneanos, es imprescindible conocer primero el contexto en que surge la serie República de la Muerte.

\section{El SalVador: Lapidario en ROJO}

El 16 de enero de 1992, el gobierno de El Salvador y las organizaciones guerrilleras -reunidas bajo el paraguas del Frente Farabundo Martí para la Liberación Nacional (FMLN)-firmaron los Acuerdos de Pazen el Castillo de Chapultepec (México). Elfin del conflicto armado llegaba después de una guerra civil que había comenzado oficialmente en 1980 y en cuyo marco se produjeron algunas de las más terribles masacres de la historia latinoamericana, como las matanzas del río Sumpul (1980) y El Mozote (1981), realizadas por el ejército contra campesinos. Asimismo, se cometieron brutales asesinatos: el de Monseñor Romero (1980), las cuatro monjas Maryknoll (1980), los jesuitas de la Universidad Centroamericana “José Simeón Cañas” (UCA) (1989) y de otras figuras políticas de izquierda y de derecha. Además, hubo cientos de torturados y exiliados, y se calcula que el número de víctimas fue de 75.000 muertos y 15.000 desaparecidos. Así las cosas, los Acuerdos de Paz representaron la esperanza de despolarizar a una sociedad fraccionada durante décadas; la oportunidad de poner en marcha cambios institucionales que refundaran la nación bajo principios democráticos. Era la primera

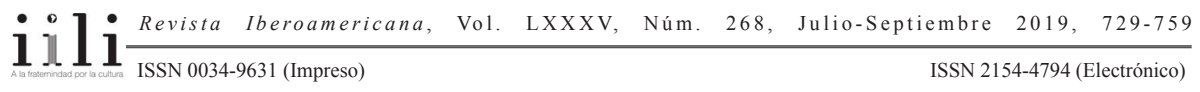


vez en la historia del país que un partido político de izquierda (el FMLN) entraba a ser parte del entramado institucional; se creaba una Policía Nacional Civil (PNC) y se ponían en marcha los mecanismos de un Estado de derecho que, supuestamente, garantizaría los derechos humanos y ciudadanos.

La firma de dichos acuerdos también se convirtió en el combustible que avivó un entusiasmo colectivo y desplegó un estallido de acontecimientos culturales: publicaciones, foros, festivales, actividades que visibilizaron las inquietudes artísticas e intelectuales de un pueblo que salía de más de una década de represión y militarismo. ${ }^{1}$ En pocas palabras, se dinamizó el campo cultural, algo que no es poco considerando la persecución que habían sufrido algunos de sus representantes. ${ }^{2}$ Sin embargo, el entusiasmo duró apenas tres o cuatro años y, hacia finales de los años noventa, se trastocó en desencanto. Los conflictos sociales que quedaron sin resolverse a pesar de esa supuesta refundación de la nación-desigualdades sociales, impunidad-convergieron en una violencia permanente, demostrando así las condiciones paupérrimas de la mayoría de la población. Asimismo, se evidenció el carácter autoritario que había existido durante décadas, el cual había dejado sus huellas en una cultura polarizada. En 1999, el escritor Miguel Huezo Mixco afirmó acertadamente lo siguiente: "La cultura, lejos de compactarnos, nos dividió. Y esa división, ese enfrentamiento, esa colisión, es el signo que nos identifica como cultura [...] El país ha venido creciendo [...] con una conciencia de progreso frágil. Y esto está en el corazón de la constitución cultural nacional" (25-26). El profundo arraigo de esos esquemas ideológicos autoritarios incluso decoloraron iniciativas culturales y paralizaron proyectos como el del periódico Primera Plana. Horacio Castellanos Moya ha relatado esta experiencia en su libro de ensayos Breves palabras impúdicas (2010), al cual ya he hecho referencia en otros escritos: ${ }^{3}$

\footnotetext{
"Aparentemente, las cosas empezaban a cambiar y lo anterior adquirió credibilidad cuando la Dirección de Publicaciones e Impresos (DPI), publicó la primera gran antología estatal de la obra poética de Roque Dalton, En la humedad del secreto (1994), compilada por Rafael Lara Martínez. Además, a mediados de los años noventa, la DPI fue sometida a una renovación importante: se le confió su dirección a Miguel Huezo Mixco, escritor y ex guerrillero, todo un hito considerando que el Estado estaba controlado por un gobierno de derechas. Asimismo, se creó la Biblioteca Básica de la literatura salvadoreña, compuesta por treinta títulos a precios bastante accesibles; se reactivó la emblemática revista Cultura, cuya publicación se había limitado a unos pocos números durante la guerra; y, además, se volvieron a instituir los Juegos Florales. Sin embargo, hacia el final de la década de los noventa, aquel entusiasmo había languidecido dramáticamente" (Pleitez Vela, "Dos lecturas del aislamiento" s/p).

2 "Recordemos que en los años setenta y ochenta, muchos escritores y poetas habían sido desaparecidos, torturados, asesinados, o habían muerto en combate: Jaime Suárez Quemain, Alfonso Hernández, Salvador Silis, Arquímides Cruz, Claudia Jovel, Amílcar Colocho, Amada Libertad, Lil Milagro Ramírez y, por supuesto, Roque Dalton, son solo algunos nombres. Incluso el oficio de librero había sido una actividad peligrosa como lo demuestra el caso de la librería Pablo Neruda: en dos ocasiones explotaron bombas en sus instalaciones; más tarde, a mediados de los años ochenta, su dueño, Reynaldo Echeverría, fue asesinado" (Pleitez Vela, s.p.).

3 Véase mi artículo "Dos lecturas del aislamiento. Lo sobrenatural y lo fantástico en Horacio Castellanos
}

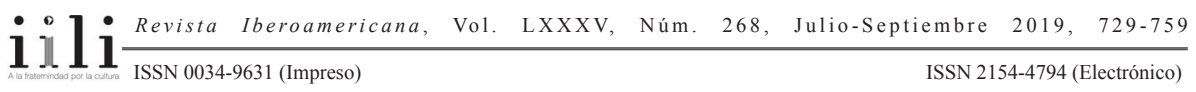


Para ese entonces [1992], un pequeño grupo de intelectuales comenzábamos a publicar una revista mensual [Tendencias], de información y pensamiento, con la que nos proponíamos colaborar en la transición a la democracia. La idea que guiaba nuestro propósito editorial era abrir un espacio de debate que ayudara a despolarizar y desideologizar la vida política y cultural de una sociedad acostumbrada a vivir en la confrontación militar de los extremos. Dos años más tarde, a principios de 1994, guiado por ese mismo propósito, participé en la fundación [...] del primer periódico de la posguerra, Primera Plana, una publicación semanal en la que se involucró con entusiasmo una nueva generación de periodistas y que buscaba ampliar los espacios para el disenso. Pronto nos ganamos la animadversión de las dos fuerzas políticas que habían contendido en la guerra civil y que ahora controlaban la vida pública institucional. Nuestra iniciativa periodística murió por asfixia financiera. [...] Ciertamente se puso fin a la práctica del crimen como método de resolución del enfrentamiento político, pero la cultura de la violencia encontró nuevos cauces. (54-55)

Las particularidades de esa polarización fueron la casi inexistencia de espacios neutrales; los fundamentalismos ideológicos y políticos (tanto de la izquierda como de la derecha); y la práctica cotidiana de la violencia. Pero lo más preocupante fue advertir una energía ciudadana mínima, es decir, pocas iniciativas de la sociedad civil que no estuvieran alienadas con alguna de las partes.

En este estado de cosas, las desigualdades sociales continuaron pulsando, mientras que la memoria histórica corría el riesgo de diluirse en las formas del neoliberalismo. No obstante, hubo un ingrediente más que terminó de agravar la situación: hacia 1996, Estados Unidos comenzó a deportar salvadoreños indocumentados y miembros de las llamadas maras, pandillas que habían nacido en las calles de Los Ángeles, pero que se habían esparcido en varias ciudades de ese país. Estos deportados llegaron al país a fundar "agencias" de la Mara Salvatrucha y la Mara de la Calle 18, comenzando así una red de crimen organizado que hoy en día, veinticinco años después, sigue desgarrando a El Salvador. ${ }^{4}$ Para conocer las atroces formas de operar de estas maras

Moya y Claudia Hernández" (2016), así como mi monografía Literatura. Análisis de situación de la expresión artística en El Salvador (2012); ambos textos están indicados en la bibliografía de este artículo.

4 En 2015, hubo 6.657 asesinatos en El Salvador, lo cual implicó un alza del 166\% con respecto a años anteriores. Esta cifra, que corresponde a la proporcionalidad de acuerdo con la población del país (6.3 millones de habitantes), adquiere dimensiones aterradoras si la comparamos con otros países. Por ejemplo, en Colombia la cifra oficial, en 2015, fue de 12.540 homicidios, pero para equipararse con la de El Salvador deberían de haber enterrado a casi 51.000. En España se asesinan a unas 300 personas al año, para vivir lo que sufre El Salvador, se tendrían que asesinar a 47.769 personas. Entre las denuncias de violaciones de derechos humanos que los salvadoreños impusieron a la Procuraduría de los Derechos Humanos, aquellas que señalan a policías y soldados pasaron de representar el $40 \%$ en 2014 al $74 \%$ en 2015. Evidentemente, se vive de nuevo una guerra, pero oficialmente no se ha nombrado como tal (Valencia s/p).

$111 \frac{\text { Revista Iberoamericana, Vol. LXXXV, Núm. 268, Julio-Septiembre 2019, }}{1129-759}$ 
y sus clicas, solo hay que ver el documental La vida loca (2008) de Christian Poveda, quien precisamente fue asesinado poco después del estreno de la película.

Hacia mediados de los años 2000, otro hecho comenzó a golpear a El Salvador: la aparición de cuerpos de mujeres jóvenes que habían sido agredidas y decapitadas. Según datos del Observatorio de Violencia de Género de la Organización de Mujeres Salvadoreñas por la Paz (ORMUSA), la mayoría de asesinatos de mujeres y niñas incluyen crueldad, mutilación y abandono de los cuerpos en barrancos o en la vía pública. Entre 2005 y 2006, se registraron 2.830 mujeres asesinadas y, cuatro años después, en el primer trimestre de 2010, 580 mujeres y niñas, es decir, un promedio de dos mujeres cada día. En la mayoría de los casos, estos asesinatos estaban precedidos por la agresión sexual (Observatorio s/p). El Salvador, pues, estaba siendo mordido por una violencia de grandes dimensiones incrustada en el tejido social.

Fue precisamente en este período que Mayra Barraza comenzó a hacer un conteo de las muertes diarias y a colocar las noticias en un blog titulado 100 días en la República de la Muerte (2006), concibiendo así una especie de "cuaderno de la memoria" del que hablaré más adelante. La realización de ese cuaderno virtual fue la fuente que llevó a la salvadoreña a crear una serie de obras artísticas por medio de las cuales se propuso decodificar la violencia, brindándole especial visibilidad a la que se lanza contra las mujeres. Su propósito, como veremos, fue instaurar escenarios visuales que representaran ese contexto, aunque sin recurrir a uno sangriento: la suya era más bien una contrapropuesta a las noticias espectaculares y amarillistas de los medios de comunicación.

\section{Mayra BarrazA: "Libre de modas y facilismos"}

Mayra Barraza nació en El Salvador en 1966 y estudió en The Corcoran School of Art, en Washington, D.C. Desde los años ochenta, se ha dedicado a las artes y ha presentado su trabajo en el Museum of Latin American Art de California, la II Bienal de Lima, la Casa de América Latina en Lyon (Francia), el Centro Atlántico de Arte Moderno en las Islas Canarias y el Museo del Barrio en Nueva York, entre otros. Ha obtenido varios reconocimientos, como el Premio Museo de Arte Latinoamericano MOLAA en Dibujo (2008) y el Premio igualitario del VI Salón de Dibujo de Santo Domingo (2007), de la República Dominicana. Está representada, básicamente, por tres galerías: saltfineart en California, Liliana Bloch Gallery en Texas y Galería 1-23 en El Salvador. Además, es una figura pública, reconocida, en el campo cultural salvadoreño: ha sido gestora y activista cultural; fundadora del programa "Mujeres en las artes"; líder del grupo de artistas que denunció sostenidamente la destrucción del mural La armonía de mi pueblo de Fernando Llort ordenada por líderes conservadores de la Iglesia católica; y, como funcionaria de la Secretaría de Cultura de la Presidencia, ha ejercido los siguientes cargos en diferentes períodos: coordinadora de la Red de

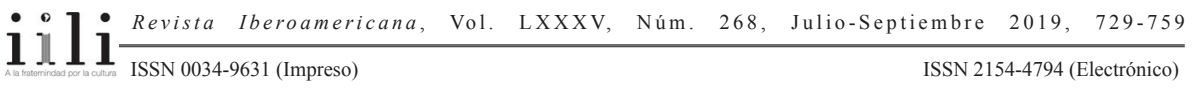


Casas de la Cultura; directora de Espacios de Desarrollo Cultural; y directora de la Sala Nacional de Exposiciones "Salarrué".

La descripción biográfica que incluye Liliana Bloch Gallery en su sitio web nos informa sutilmente sobre la "idea de artista" que se le adjudica: "Currently she divides her time in El Salvador between the walls and tasks of the Presidential Secretariat of Culture and her studio-residence surrounded by vegetation and birds" (Liliana Bloch Gallery s/p). Es decir, se evidencian tres aspectos transversales: el trabajo cultural, la dedicación al arte y el contacto con la naturaleza. Una mujer, pues, con varias aristas: es una artista dedicada y disciplinada (vive en un estudio-residencia); no está encerrada en una torre de marfil, aislada, pues se mueve en lo público como gestora cultural; y está rodeada de una vegetación tropical, indómita, resistente. A mi parecer, esta descripción se acerca a la noción de mujer que ha aparecido en la obra de Barraza. Precisamente, la salvadoreña ha creado una serie de mujeres, ya sea vestidas, desnudas o semi-desnudas, con posturas despreocupadas - que para algunos podrían parecer provocadoras- que emanan soltura, seguridad, firmeza; la serie se titula Feral Female, donde feral, según el diccionario de Oxford, es la palabra inglesa para describir a un animal en estado salvaje, especialmente después de fugarse del cautiverio o la domesticación.
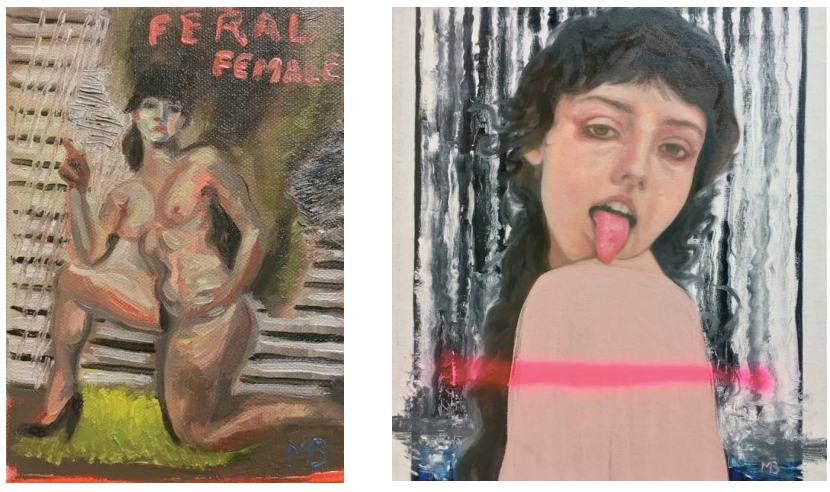

Imágenes 1 y 2

Dos pinturas de la serie Feral Female (2017) (C)

Óleo sobre tela y óleo con aerosol sobre tela, respectivamente, 18 x $12 \mathrm{~cm}$

Esta serie está acompañada de un paratexto de la artista que dice lo siguiente: "Unspoken to and unheard of. Women on the fringe, undomesticated" (Myra Barraza s/p). La idea que subyace es la de una femineidad no domesticada a estándares o estereotipos convencionales, por lo general masculinos. De alguna forma, se transparenta el retrato de una artista insumisa, anti-establishment que, sin embargo, también intenta manejar sus cartas ya que simultáneamente opera en el establishment cultural como gestora,

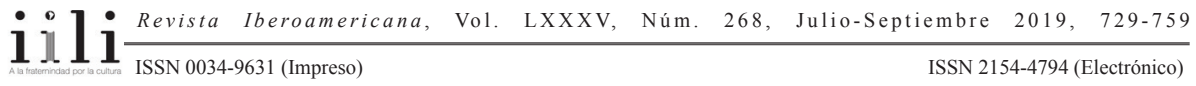


con el propósito de promover y difundir el arte salvadoreño en un país precarizado, sobre todo el arte realizado por mujeres que se resisten al "cautiverio" (donde el término excede lo íntimo, el espacio del "fogón", ya que la cotidianidad vivida en medio de una violencia de grandes dimensiones también es un cautiverio). Pareciera que resistencia -y las reflexiones que se desprenden de esa resistencia- sea el lápiz que traza al personaje barrazaneano.

Eleonora Cróquer se ha detenido especialmente en lo que ella ha llamado "caso de autor", es decir, aquellos "anormales", "excéntricos", "bichos raros", que tradicionalmente le han dado " "de qué hablar' a la cultura”, y ha analizado cómo estos se han leído e investigado (93). En ese sentido, la crítica tradicional, por lo general, ha instituido a las autoras como ese Otro-enigma, "difícil de comprender", en oposición al concepto de autor en masculino: creador genio, singular y soberano. Las autoras entonces se convierten en un "caso extraordinario", representan a las "excepciones", las escandalosas, incluso las Pitonisas extraviadas por su deseo. Para comprobarlo, solo hay que acercarse a la reescritura que hizo Alberto Zum Felde sobre Delmira Agustini, por ejemplo. De esta forma, asegura Cróquer, la representación de autora también se convierte en artefacto cultural. ${ }^{5}$ Lo anterior se debe a que la normativa que gobierna a la representación del concepto de autor, resulta incompatible con la del género femenino. Esta incompatibilidad se asienta en la oposición creación y reproducción (Stanford Friedman citado en Pérez Fontdevila y Torras 48), lo cual establece una división sexual del trabajo: las mujeres son identificadas sobre todo con sus funciones biológicas, por lo tanto, como categoría ideológica, no representan a aquel creador definido por su encastillamiento en un fuero interno que, supuestamente, certifica la autenticidad y la originalidad de la obra (Pérez Fontdevila y Torras 48).

Barraza ha acentuado esta problemática en el contexto de un país con un campo cultural precarizado, al tiempo que ha explorado los espacios de poder. En el catálogo de la exposición A cielo abierto. Construcciones espacio-temporales de género (2016), curada por la misma Barraza y dedicada a obras de artistas salvadoreñas nacidas entre 1938 y 1984, se incluye una introducción que bien pudiera ser una declaración de principios:

La intención curatorial fue la de visibilizar el trabajo de mujeres artistas de generación media que no han tenido la oportunidad de mostrar su obra con la frecuencia de otras artistas de generaciones mayores o menores, que cuentan con más oportunidades expositivas. Rápidamente descubrí que el enfoque generacional no es el más efectivo porque las condiciones de trabajo de las mujeres artistas son tan determinantes en su producción. La línea de desarrollo para una mujer artista por lo general no inicia en

Véase el libro de Eleonora Cróquer, Escrito con rouge. Delmira Agustini (1886-1914), artefacto cultural.

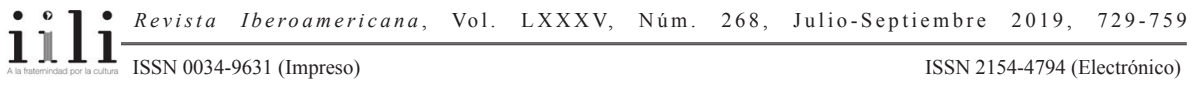


formación para luego pasar a diferentes grados de profesionalización y reconocimiento. Al contrario, su línea evolutiva es errática y obedece en la mayoría de los casos a factores externos a sí mismas y a sus ambiciones como artistas. Las mujeres artistas se ven condicionadas a estudiar carreras (en el mejor de los casos) que les procuren manutención a ellas y a sus familias, para luego dedicarse a trabajar y generar ingresos al mismo tiempo que asumen un alto porcentaje de la carga doméstica en cuidado de sus hijos. Al verse obligadas a priorizar, su tiempo para el desarrollo artístico se ve sacrificado. Esta situación ha sido evidente a lo largo de la historia del arte universal, pero ahora se vuelve insostenible y debe procurar ser remediada de manera enérgica por aquellos en la posibilidad de hacerlo. Es una responsabilidad del Estado, en cumplimiento con nuestra constitución, el procurar espacios de expresión y acceso a la cultura para todos sus ciudadanos, y las mujeres no deben ser la excepción. (Barraza, "A cielo abierto" 12)

Y más adelante agrega:

Aquí es necesario hacer un ejercicio consciente por evitar caer en las lecturas más tradicionales acostumbradas a identificar a las mujeres simbólicamente con la naturaleza o encarnando alegóricamente los ideales de la nación, sometidas como sujetos pasivos; en una a su función de reproducción biológica, y en la otra a un ideal patriarcal fundacional del cual es excluida su participación activa. (ibid.)

Vemos, pues, que Barraza subraya la participación activa de las mujeres en todos los espacios, incluidos el íntimo y el público. Además, en esta reivindicación, la salvadoreña no ha omitido la disección de la masculinidad. Por ejemplo, en su serie Waters of Lethe (2010-2012) [Aguas de Leteo], Barraza reflexiona sobre la historia del arte, la figura masculina y la idea del arte como vehículo para navegar en la memoria. Precisamente, el título de la serie deriva del famoso poema de Allen Gingsberg, "A Supermarket in California", en el que el yo poético hace un recorrido por el supermercado al tiempo que evoca la presencia de Whitman y hace una crítica a la sociedad de consumo; al final se mencionan las aguas negras de Leteo, el río del olvido. Al respecto, Barraza comenta: "Me pareció un abordaje interesante, entrar a la historia del arte y repensar el canon histórico desde una perspectiva femenina y, además, latinoamericana, y hacer una propuesta a partir de esos ejes, basados en la mitología" ("Entrevista personal" s/p). Al observar la serie, compuesta por retratos de hombres difuminados, casi borrados, tal si fueran los ecos de una pérdida, pareciera que Barraza se haya preguntado lo siguiente: ¿Qué pasaría si esos hombres artistas que han dominado la historia fueran condenados a navegar el río del olvido, tal y como les ha sucedido a tantas mujeres artistas? No queda duda de que la figura de autora de Barraza está moldeada desde una posición cuestionadora e interrogadora de la cultura e indomesticada por las convenciones. Lo anterior se aprecia visualmente si nos detenemos en una fotografía de 2014, publicada

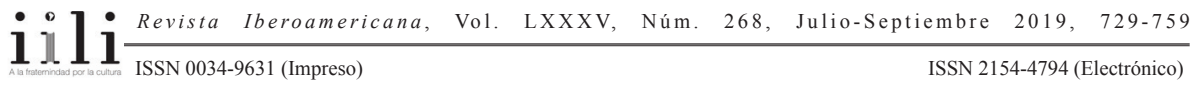


en La Prensa (Nicaragua), donde la artista aparece junto a "Holbein's Ship IV" de la mencionada serie Waters of Lethe: ahí está la imagen de la masculinidad desvanecida, disipada, contrapuesta a la imagen de la autora, que con entereza y despreocupación mira a la cámara mientras agarra un cigarrillo entre sus dedos:

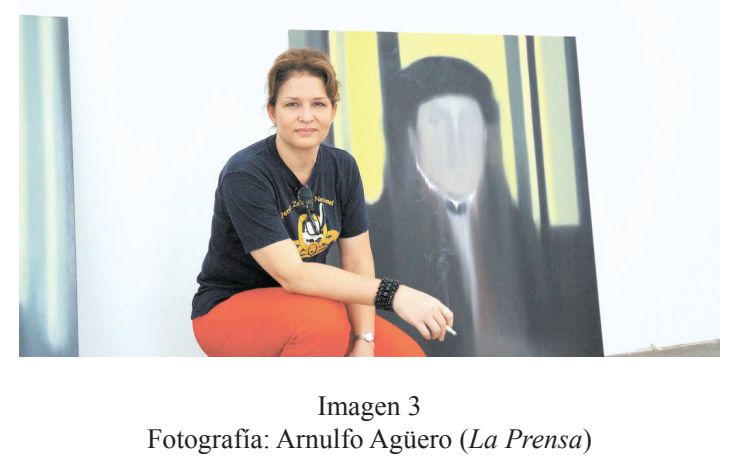

La figura de autora que Barraza saca a escena también se comprueba cuando, al citar en su sitio web una entrevista que le hiciera Ramiro Lacayo Deshon -publicada en la revista Carátula en 2011-, ella decide titularla con una de las frases del entrevistador: "libre de modas y facilismos", y no con el título propio de la misma: "Siempre que puedo retorno a los clásicos" ( $\mathrm{s} / \mathrm{p})$. La imagen de mujer y artista libre, con criterio propio, comprometida con temas ciudadanos en un país polarizado - un lugar donde la energía ciudadana era supuestamente mínima y prevalecía la idea de un campo cultural frágil-, emerge para provocar, romper. Lo mismo se percibe a partir de las siguientes fotografías, donde aparece nuevamente con el cigarrillo entre los dedos, la mirada penetrante, el rostro agudo; o fumando, aparentemente despreocupada, aunque pensativa. $\mathrm{Al}$ respecto comenta: "Las hizo el fotógrafo Sandro Stivella cuando tenía mi estudio en La Fábrica, y me pidió que me pusiera algo negro. De casualidad tenía esa camiseta con el logo de Nike, que es la figura de la victoria. Las fotos tienen un significado especial para mí. Él [Stivella] es un gran retratista y creo que logró retratar esa idea de fortaleza y fragilidad que resume a cualquier persona" ("Entrevista personal" s/p).

\begin{tabular}{l}
-111 Revista Iberoamericana, Vol. LXXXV, Núm. 268, Julio-Septiembre $2019, \quad 729-759$ \\
\hline ISSN 0034-9631 (Impreso)
\end{tabular} 

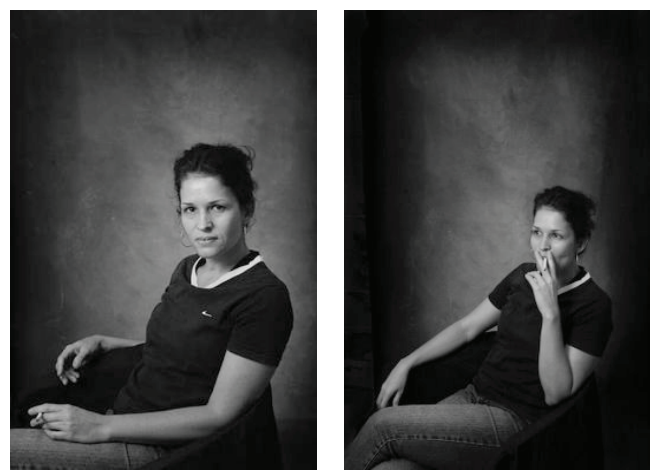

Imágenes 4 y 5

Fotografías: Sandro Stivella C

\section{Desentrañar una República de la MUerte}

¿Cómo se trasluce el papel de autora en la obra de Barraza? ¿De qué forma interroga y coloca a su personaje en un escenario elegido para "producir verdades"?

Hacia mediados de la década de los años 2000, ante el clima de violencia que ya he descrito anteriormente; la apatía e indiferencia que reinaba, sobre todo entre las élites encerradas en sus mansiones, verdaderas jaulas de oro; el amarillismo desplegado por la prensa del establishment; la política de mano dura del gobierno; y la ausencia de un diálogo reflexivo que abordara las causas de esa violencia -la inequidad social, la pobreza extrema, la discriminación, el clasismo, la deshumanización, la desestimación de la memoria histórica, la impunidad, una cultura extremadamente conservadora, por mencionar las más obvias-, Barraza creó un blog titulado 100 días en la República de la Muerte. ${ }^{6}$ Específicamente, se comenzó el 1 de septiembre de 2006 y el mismo estaba precedido por este comentario de la artista en el que reconoce la influencia de la periodista y escritora salvadoreña, Carmen Tamacas, en la gestación de la idea:

El proyecto "100 días" es un conteo de los muertos por actos violentos (no por causas naturales, no por accidentes, sino directamente de la mano de otro) en El Salvador durante 100 días. Los datos los sacaré exclusivamente de los dos principales medios escritos: LPG [La Prensa Gráfica] y EDH [El Diario de Hoy]. La idea no es mía. Carmen Tamacas lo propuso hace dos años entre un grupo de artistas que conversábamos sobre qué hacer para contrarrestar la escalada de violencia. Ahora, la retomo en este formato de blog, esperando hacer memoria de todos los muertos, y esperando que al

6 Se pueden consultar algunos fragmentos del blog siguiendo este enlace: $<$ http://repblicadelamuerte. blogspot.com.es/>.

$111 \frac{\text { Revista Iberoamericana, Vol. LXXXV, Núm. 268, Julio-Septiembre 2019, }}{1129-759}$ 
menos arroje preguntas importantes sobre lo que sucede, como: ¿Por qué? y ¿Hasta cuándo? (Barraza, Documento facilitado $\mathrm{s} / \mathrm{p}$ )

El objetivo más visible del blog era sacudir la "fatiga de compasión", en palabras de Martha Rosler (citada en Albán s/p), para referirse a la incapacidad de asombro, la insensibilidad y la falta de compasión por parte de la ciudadanía, al estar expuesta rutinariamente a imágenes y noticias extremas. No obstante, su propósito de llamar la atención sobre la devaluación de la vida humana iba acompañado de la extracción de datos que mostraran un matiz en ese mar de crímenes violentos, es decir, era también una especie de álbum o cuaderno, pero como esfuerzo para abrir una rendija por la que ver e interrogar. Así, durante cien días, la artista anotó sus reflexiones sobre ese momento de la historia de la violencia salvadoreña, pero también conversaciones con amigos y mensajes recibidos de los lectores, cuyo espectro iba desde ciudadanos de a pie hasta escritores y artistas, como Claribel Alegría, Jacinta Escudos, Lolita Bosch, ${ }^{7}$ Manlio Argueta, José Osorio, Claudia Hernández ${ }^{8}$ y Carmen González Huguet; transcribió las noticias sobre los asesinatos que aparecían en La Prensa Gráfica y El Diario de Hoy; comentaba el tratamiento que se le daba a dichas noticias; incluía artículos sobre la precarización y la violencia en otros lugares del mundo; ${ }^{9} \mathrm{y}$, además, en ocasiones escaneaba las fotografías de las víctimas (en aquel entonces, dichos periódicos no contaban con una versión digital). Cito a continuación cuatro anotaciones de Barraza, a manera de ejemplo:

\section{1 septiembre 2006}

Comienzo este ejercicio con la sensación de estar haciendo algo contra el sentido común. Las personas normales no buscan la muerte. La rehúyen. Quizás buscan la vida. Yo también. Pero no puedo seguir así. Leo el periódico todos los días. De atrás para adelante. “¿Por qué?”, me pregunta mi hijito de 9 años. "Prefiero comenzar por

\footnotetext{
7 Precisamente, en la actualidad la escritora Lolita Bosch coordina la organización Nuestra aparente rendición, conformada por escritores, periodistas e intelectuales, de la cual ha derivado el proyecto Menos días aquí, el cual mantiene, desde 2010, un blog y una cuenta de Twitter dedicados a recolectar los nombres de las víctimas de la violencia en México, sin importar bandos y tendencias mediáticas.

8 La reconocida narradora Claudia Hernández le envió a Barraza tres cuentos para publicar en el blog: "Hechos de un buen ciudadano" (Parte I), "Melissa: Juegos 1 al 5" y "Cuando el hijo está en forma de trozos [Manual del hijo muerto]". Fueron publicados el 7, 8 y 9 de octubre, respectivamente. Estos cuentos forman parte del libro Mediodía de frontera (2002).

9 Por ejemplo, en la entrada del 19 de septiembre de 2006, Barraza transcribe al completo un artículo de Sergio Ramírez titulado "El niño, el buitre y el cerdo", aparecido en Página 12, en el que el escritor nicaragüense se refiere a la mirada y al trabajo del artista en escenarios de horror (hambrunas, guerras, etc.). El artículo cierra con esta frase, la cual conecta con lo que Barraza realizaba en ese momento: "Al fin y al cabo, el artista no es responsable del horror. No lo produce. Y no puede dejar de hacer su oficio, que es registrarlo" (Ramírez s/p).
}

$111 \frac{\text { Revista Iberoamericana, Vol. LXXXV, Núm. 268, Julio-Septiembre 2019, }}{1129-759}$ 
las noticias más bonitas" -le digo- "las de cultura". Al acercarme a las noticias de nacionales, día tras día, me choca lo que veo: los crímenes cometidos, la sordidez de los hechos, y la ligereza con que pasan a sumarse una y otra vez al olvido. Conversando con un amigo sobre lo que quería hacer con este blog, me hacía una interesante observación: "los muertos no los vemos, no están en la calle, están en las noticias". Me hizo dudar, como si dispusiera a meterme a un mundo de sombras, donde no se reconoce la realidad de la ilusión. Pero allá voy, estoy dispuesta a ello. Quiero saber...

\section{2 septiembre 2006}

Me ha quedado resonando del día de ayer la pobre mujer muerta completamente fracturada.

\section{0 septiembre 2006}

Comencé porque estaba asustada de la cantidad de mujeres asesinadas y de la cantidad de cuerpos que aparecían desmembrados. [...] me doy cuenta, en estos pocos días de ver atentamente lo que sucede, que las víctimas son en su mayoría hombres jóvenes que mueren por disparos.

\section{1 septiembre 2006}

Por primera vez en lo que llevo este conteo aparece la foto del rostro de una de las víctimas. Quizás, porque fue asesinado en su casa, tuvieron acceso a alguna foto personal en la vivienda. Publicaron otra foto, de sus restos calcinados en el lugar, prefiero colocar esta de su rostro. Es un rostro compungido, afilado, el ceño ligeramente fruncido, los labios apretados. Parece mirar a la cámara molesto, como forzado. Tiene rasgos indígenas: piel oscura, nariz larga y quebrada, pómulos altos, ojos rasgados y poco vello facial. Su cabello esta [sic] alborotado casualmente y es más largo de lo que se acostumbra. Alcanzo a ver que lleva puesta una camiseta y encima quizás una sudadera. Hay una imagen reflejo a un lado, pareciera que fue fotografiado frente al retrato de alguien. El periódico dice que "se dedicaba a recoger latas cerca del río" pues vivía a la orilla de una quebrada. Douglas es su nombre. "Solo mueren los nombres" leí en algún lado el otro día. (Barraza, 100 días Documento s/p)

A lo largo de esos cien días, la artista registró un total de 575 asesinatos, cita espeluznante considerando que gran parte de las muertes violentas no se reportan en los medios. Durante el proceso de documentación, Barraza identificó dos recurrencias: 1) la mayoría de las víctimas no eran mareros ni policías, sino gente común asesinada en sus lugares de trabajo, esparcimiento o habitación (en ese momento, las maras todavía se encontraban expandiendo sus territorios); 2) un tipo de asesinato del que entonces no se hablaba directamente en los medios: la aparición de cuerpos de mujeres jóvenes, algunas adolescentes, decapitadas, desmembradas, o con los huesos fracturados. Barraza, pues, reconoció el feminicidio dentro de esa ola de asesinatos. Sobre esto último volveré más adelante. 


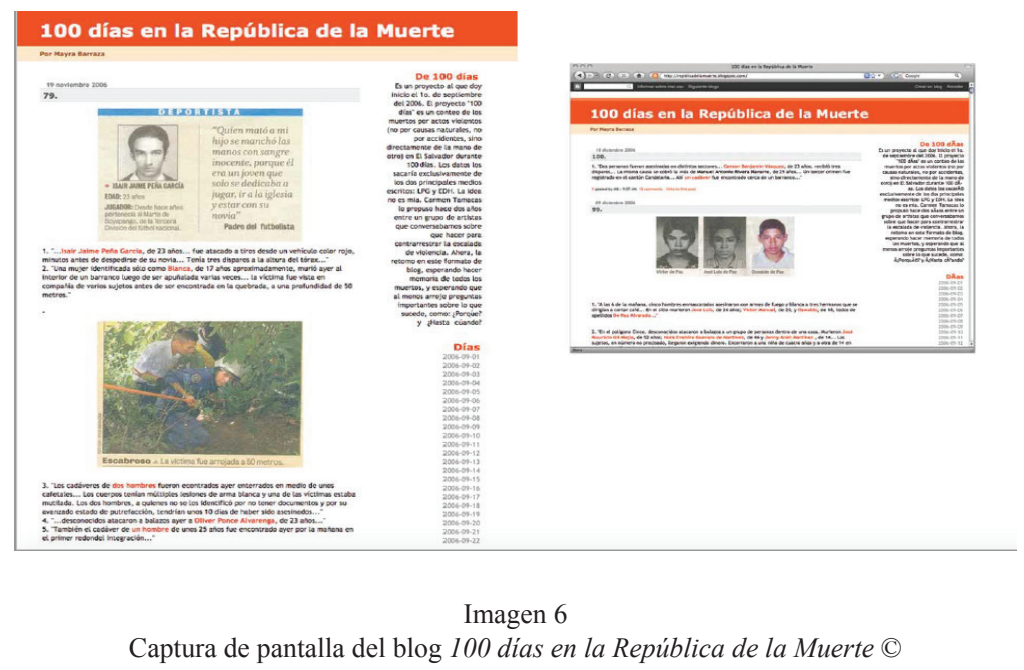

En retrospectiva, podríamos decir que se trata de una especie de archivo híbrido y heterogéneo: por un lado, se establece como una bitácora personal donde la artista registra los asesinatos y sus propias impresiones, incluyendo pronunciamientos políticos y opiniones de intelectuales. Por otro lado, es un lugar de encuentro de la comunidad puesto que los lectores también "hacen" archivo. Por ejemplo, El Visitador -pseudónimo de uno de los comentaristas más activos del blog-colabora realizando el conteo de víctimas, contrasta datos y brinda información forense y criminalística. Al respecto, Barraza comenta lo siguiente: "He visitado el blog de El Visitador y [...] me he encontrado con un observador acucioso e informado de la 'realidad' salvadoreña. Me alegra [de que me] acompañe [en] este horrendo recuento enviando las cifras a diario" (Barraza, 100 días Documento $\mathrm{s} / \mathrm{p}$ ). La artista también incorpora a su discurso los comentarios enviados por los lectores, como es el caso de Eddie Palmera quien, después de narrar un robo a mano armada, señala que "la violencia va llamando a la violencia, todos los teléfonos de la muerte están conectados entre sí de un modo invisible. Suenan constantemente los teléfonos, a todas horas"; Barraza reacciona escribiendo lo siguiente: "Me ha impactado mucho esa imagen. Pensar que cuando uno comienza a buscar las razones de tanta violencia [...] y suenan esos teléfonos a todas horas..." (ibid.).

Asimismo, Barraza integra referencias artísticas y citas literarias porque, según sus propias palabras, "necesito ver de que [sic] manera otros artistas abordan el tema de la violencia, de la muerte. Quizás para no sentirme sola [...], quizás para ayudarme a reflexionar, o para sentir que algo trasciende más allá del hecho violento, del cuerpo agredido" (ibid.). De esta forma, en la entrada del 24 de septiembre, incluye un dibujo

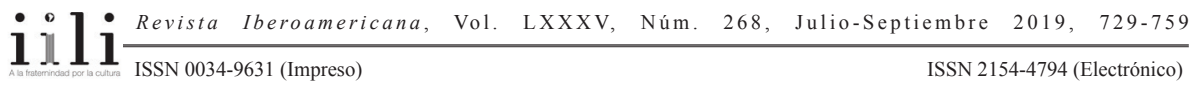


del artista Luis Caballero y dos poemas de Harold Pinter en traducción de Andrew Graham-Yooll. ${ }^{10}$ En otras ocasiones, Barraza incluso llega a deconstruir el texto de las noticias y crea poemas visuales, nutriéndose de la intertextualidad, como en la entrada del 10 de octubre:

Rosa Fuentes de 25 años, "fue muerta a balazos en el Cantón El Güisquil... Al
momento del ataque compraba tortillas en una tienda cerca de su vivienda".

compraba tortillas en una tienda cerca de su vivienda

compraba tortillas en una tienda cerca

compraba tortillas en una tienda

compraba tortillas

compraba

rosa fuentes fue muerta a balazos

fuentes fue muerta a balazos

muerta a balazos

a balazos.

(Barraza, 100 días Documento s/p)

A partir de ese tejido de voces - la de Barraza y las de la comunidad, contrapuesta al amarillismo deshumanizado de las noticias-, entre 2006 y 2009, la artista realizó trece series en el marco de lo que luego llamaría República de la Muerte. ${ }^{11}$ En 2010,

${ }^{10}$ Los dos poemas de Harold Pinter citados son "Muerte" y "Reunión". Me interesa destacar el poema "Muerte" ya que es este, precisamente, uno de los textos que también será utilizado seis años después por la escritora mexicana Sara Uribe en su pieza conceptual Antígona González (2012), en la que intervienen tres estrategias: la apropiación, la intervención y la reescritura. El poema en referencia comienza: “¿Dónde se halló el cadáver? ¿Quién lo encontró? ¿Estaba muerto cuando lo encontraron? ¿Cómo lo encontraron? ¿Quién era el cadáver?”, etc. En el poema de Uribe, las preguntas de Pinter son respondidas por diversos testimonios de familiares de los desaparecidos extraídos de notas periodísticas.

11 Estas series son: "El cuerpo del delito", dibujos $(50$ x $70 \mathrm{~cm}$.) en acuarela y materiales varios (20062007); "Himno Nacional", instalación de 500 listones bordados con los nombres de los asesinados, de los que cuelgan pequeñas campanas en sus extremos (2007); "Brazos", esculturas de bronce sobre grama (2006-2008); "El sueño de la razón”, acuarelas (50 x 70 cm.) (2006-2008); “Un saludo desde la hermana República de El Salvador", acción en el centro de San Salvador/vídeo (2006/2008); "Jardín doméstico", acuarela sobre papel y joyero (ensamblaje) y acuarela sobre papel y grama (2006-2008); "Escena de liberación", audio intervenido que contiene la voz de una fiscal anónima que se desahoga (2007) (en abril de ese año, una fiscal de San Salvador contactó con Barraza, a raíz del blog y de la serie "El cuerpo del delito". La fiscal pidió reunirse con la artista con la condición de mantener su anonimato. Según lo relatado a Barraza, ella necesitaba desahogarse con alguien sobre los horrores que presenciaba a diario: no hablaba de ellos con su familia porque no quería llevar esas imágenes de terror a su hogar; mientras que con sus colegas hombres, no se podía permitir mostrar sus emociones, pues temía ser considerada "demasiado blanda" para el trabajo. La fiscal accedió a ser grabada); "Danza de los muertos", vídeo performance de 7’45 minutos (2008); "El libro de los muertos”, setenta retratos de víctimas de asesinatos, en acuarela y en pequeña escala, expuestos de tal manera que forman la palabra 
las series fueron reunidas en una exposición y, después, en un catálogo publicado por el Centro Cultural de España de Honduras y la Agencia Española de Cooperación Internacional para el Desarrollo (AECID). Este incluye paratextos de dos reconocidos escritores centroamericanos, Rodrigo Rey Rosa y Horacio Castellanos Moya. Este último afirma lo siguiente:

Para la artista resulta difícil mantener la ecuanimidad con material de trabajo tan saturado de emociones extremas. Los motivos vienen de siempre y se repiten: el velorio y el entierro con los llantos desgarrados, el cadáver sin identificar y completamente despedazado, los rostros estupefactos por el sempiterno terror, las autoridades impotentes o cómplices, los familiares de la diáspora exigiendo justicia y ofreciendo apoyo y solidaridad. La tentación fácil para la artista ante esos motivos sería la denuncia, la indignación que cae en el kitsch, la inutilidad del panfleto. De esto parece consciente Mayra Barraza: intuye que su virtud radica en la singularidad de su mirada, en el pulso firme para recoger esas pasiones extremas y reinventarlas con el lenguaje del arte. Decía un viejo místico: "Para un hombre que no está atado a nada interno, Dios es miedo y violencia". La apuesta de la artista es precisamente ésta: con la materia maleable del miedo y la violencia construir una obra perdurable. (Castellanos Moya, "La apuesta" 6; cursivas personales)

En contraste, el escritor guatemalteco Rodrigo Rey Rosa se concentró en la serie "Lapidario", una pieza múltiple de acuarelas confeccionada a partir de noticias de asesinatos extraídas de la prensa escrita durante treinta días consecutivos, las cuales fueron transcritas con plantillas distorsionando el orden del texto. Así, Rey Rosa alternó su comentario con las noticias que la misma Barraza había plasmado en sus acuarelas, reconociendo cierta intertextualidad:

Con estas treinta acuarelas Mayra Barraza parece que quiere crear un sujeto extraordinario. Alguien que se pregunte a sí mismo: ¿De dónde proviene esta violencia? Pero no se trata de una pregunta policial-ya sabemos que aquí la ley dejó de funcionar hace bastante tiempo. Se trata de hablar con nosotros mismos acerca de un medio del que formamos parte y que nos determina al mismo tiempo, y para eso tal vez haga falta un espejo, o, al menos, una mirada oblicua.

Hallan cuerpos de jóvenes atados con las manos hacia atrás... En ese lugar fue asesinado con arma de fuego... Hallan cadáver decapitado... Aparentemente murió ahogado en

porqué (2008); “Ayer soñé mi cuerpo cubierto de sangre”, ensamblaje con bordado de hilo de seda y gasa sobre lienzo (2008); "Agrupaciones ilícitas", retratos al óleo (99 x $99 \mathrm{~cm}$.) de cinco hombres apresados por el cargo de "agrupación ilícita" y asesinados por estrangulación en la cárcel (2008-2009); "Cabeza rodante", grabado (2009); y "Lapidario", pieza múltiple de acuarelas (40 x $32 \mathrm{~cm}$.) (2009). Casi todas las series pueden verse y consultarse en el sitio web de la artista: $<$ http://www.mayrabarraza. $\mathrm{com} />$.

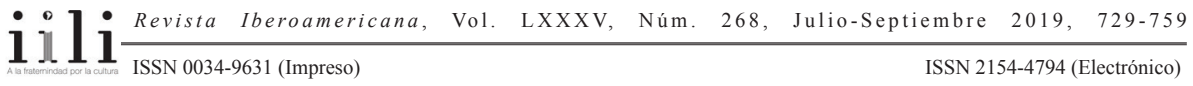


el río, aunque extraoficialmente la versión es que lo asesinaron y dejaron su cuerpo en la fuente... Matan a mujer... Frases lapidarias, sin duda, pero que no parece que hayan sido escritas para perdurar; al contrario.

La nota roja periodística (y periódica) es tan nuestra y tan efímera como los anuncios de cerveza, de ropa íntima, de autos de lujo o de bloqueador solar. (48)

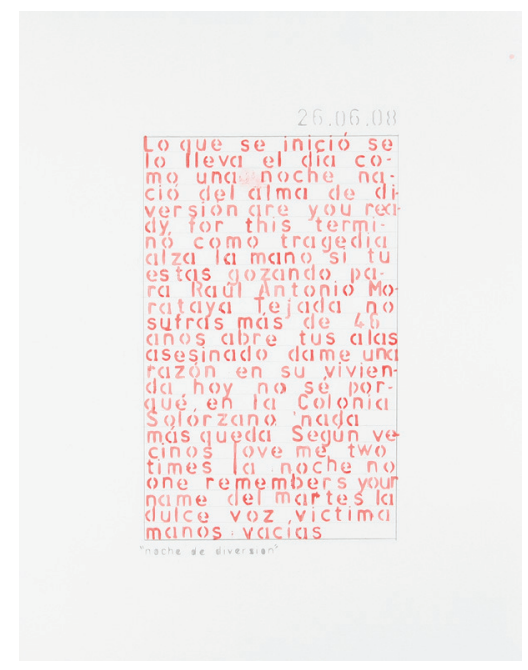

Imagen 7

Lapidario (2009) (C)

Por su parte, el escritor Miguel Huezo Mixco destacó la importancia del blog en cuanto guardián de la memoria y perfiló la imagen del artista (en masculino) vidente en el "país de los ciegos", refiriéndose indirectamente, también, a la noción de artista prodigioso, singular:

La iniciativa "Cien días en la República de la Muerte" es, en este sentido, un esfuerzo del artista por aludir a la memoria. Todos guardamos una caja con recuerdos, un álbum, un baúl, cuadernos, asesorándolos como parte de la memoria individual. Aquí, lo que se hace es recolectar los sucesos y las muertes. No es una denuncia, porque la denuncia por sí sola no agrega nada a lo que ya sabemos. Y esto es hacer mucho con lo poco: intentar que los hechos desperdigados en los noticiarios, la nota roja, estructurada como otra parte de la oferta del entretenimiento, abra en nuestras conciencias una rendija que quema, que pregunta. (s/p.; cursivas personales) 
Por último, la crítica e investigadora Evelyn Galindo se refirió al carácter contra hegemónico de República de la Muerte, "un diálogo estético con los discursos de formación del estado nacional después de 1992" (s/p). Es decir, ubicó a la obra y a su autora en el plano del discurso de la nación, pero no el que emana de la ciudadanía, sino que aquel que ha construido el imaginario desde el poder. Ante esos discursos que resultan huecos cuando se contrastan con la realidad de una refundación fallida, aquí el arte y la denuncia no aparecen separados, sino que más bien constituyen un binomio, efectivamente, contra hegemónico, de protesta:

Con un enfoque en el cuerpo humano y en la violencia corporal la exposición de Mayra Barraza presenta una producción cultural contra hegemónica independiente ya desligada de los discursos políticos de las derechas e izquierdas y revela un compromiso con representar y denunciar la realidad cotidiana. Al mostrar la aceleración de la inseguridad y de la violencia corporal después de la firma de los Acuerdos de Paz, su obra cuestiona los mismos discursos de "paz" y "posguerra" y sugiere que los traumas históricos irresueltos de la guerra de los 70-80s se inscriben en los cuerpos actuales. (s/p)

Llama la atención que en estos comentarios -aparte de subrayar la singularidad y la mirada cuestionadora de la artista-no se mencionen específicamente las voces de la comunidad (ciudadanos, artistas, escritores) que la nutrieron y acompañaron durante esos cien días, cuando escribía el blog. Como hemos visto anteriormente, según las diversas propuestas teóricas (Meizoz, Diaz y Maingueneau), la imagen de autor/a resulta vital para su reconocimiento y su posicionamiento en el campo cultural, pero al mismo tiempo aquella noción tradicional de autor/a singular u original se diluye, lo que provoca que pierda primacía como estatuto soberano; lo anterior deriva, precisamente, del carácter intertextual de todo producto cultural, es decir, ninguna singularidad es inmune a las influencias de otros; más aún, convertirse en autor/a es un proceso que no tiene lugar exclusivamente en la habitación propia, recluida, solitaria, sino en la escena social y política: "una escena en la cual la autorialidad depende de la mirada ajena y, por tanto, de la institución de una imagen reconocible y doblemente impropia: construida mediante relatos colectivos, y vulnerable a las múltiples reelaboraciones y reescrituras de los agentes del campo cultural" (Pérez Fontdevila, Torras y Cróquer 23-24). La omisión de dicha heterogeneidad y de la apretada intertextualidad (noticias de prensa, textos literarios, crónicas), en los comentarios arriba citados resulta, pues, significativa: viene a ser una especie de cincel que limpia el exceso de piedra para dejar relucir, brillar, la imagen de una artista que disputa, polemiza, y que, comprometida con la estética, se mantiene en solitario buceando en las aguas del "lenguaje del arte". Lo anterior no es una falacia, por supuesto, pero, en mi opinión, resultaría contundente y exacto mencionar la interacción establecida con la comunidad durante el proceso de creación de ese cuerpo intertextual, sobre todo porque se trataba de un país en

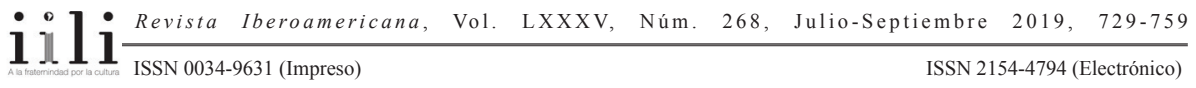


posguerra, donde no estaba visibilizada una energía ciudadana que trascendiera la polarización; dicho blog fue, evidentemente, el terreno fértil desde donde germinaron las semillas de las trece series, pero también permitió la apertura de un espacio, un verdadero diálogo ciudadano, fuera del poder, que todavía hoy se echa de menos, sobre todo en la era de las redes sociales cuando la descalificación se vuelca rabiosamente sobre quien "no piensa como yo".

Por razones de espacio, en este artículo solo comentaré los dibujos de la serie "El cuerpo del delito" (premiada en el VI Salón de Dibujo de Santo Domingo en octubre de 2007), los cuales también dialogan con "El sueño de la razón” y "Cabeza rodante".

\section{“EL CUERPO DEL DELITO” y OTROS ESCENARIOS}

El segundo paratexto del catálogo República de la Muerte es de la autoría de Barraza y constituye una especie de negociación discursiva entre la obra que interpela a la sociedad; el yo íntimo que se asoma y es intuido, adivinado, por el receptor; y la artista que se sueña, es decir, se recrea, como un cuerpo trastocado, violentado. Esa especie de espejeo corporal viene a ser el recurso, la herramienta, que le sirve a la autora tanto para inscribirse como ciudadana y artista, como para testimoniar a los otros, a las víctimas:

En un lugar no muy lejano, al cabo de 100 días siguiendo la más oscura de las noches, ondea la bandera blanca de República de la Muerte.

En este espacio imaginario confluyen fragmentos de la realidad marcados por el horror y la pesadumbre. Las noticias de última hora forman un lapidario de textos abigarrados con mensajes crípticos.

En República de la Muerte gobiernan tres poderes elegidos por el pueblo: la apatía, la ignorancia y la voracidad. Aquí la vida no tiene valor: los cuerpos humanos son tan solo fragmentos que se olvidan al anochecer.

Corazón y razón conviven separados por el filo de un arma blanca. La voz de una cabeza que rueda se multiplica. Paciente espera, bordando sus sueños:

ayer soñé mi cuerpo

cubierto en sangre. (Barraza, República 9)

Es importante señalar que Ana Mendieta influyó fuertemente en Barraza durante este período. ${ }^{12}$ Merece la pena que recordemos la impactante recreación que en 1973

${ }_{12}$ En el catálogo de República de la Muerte, la referencia del vídeo-performance "Danza con los muertos"

$111 \frac{\text { Revista Iberoamericana, Vol. LXXXV, Núm. 268, Julio-Septiembre 2019, }}{1129-759}$ 
hizo la artista cubana-neoyorkina de la escena de una violación utilizando su propio cuerpo. Conocida como Untitled (Rape Scene), la acción artística fue documentada en una fotografía en la que aparece una mujer desnuda de la cintura para abajo, con el tronco doblado sobre una mesa; tiene sangre en el trasero, las caderas y las pantorrillas; sobre el suelo oscuro se ve un charco de sangre y pedazos de vajilla rota; la escena está iluminada de forma dramática, poniendo especial énfasis en sus piernas y parte de la mesa, al mismo tiempo que se proyecta una gran sombra en la pared. Esta acción fue realizada en el apartamento de Mendieta en Iowa City, cuando era estudiante en la Universidad de Iowa, y viene a ser una respuesta a la brutal violación y el asesinato de una estudiante de enfermería, Sara Ann Otten, por otro estudiante, en marzo de 1973. Al mes siguiente, la artista invitó a sus compañeros universitarios a su apartamento; dejó la puerta entreabierta y, al entrar, estos encontraron a Mendieta en la posición antes descrita (Manchester s/p). En 1980, la artista afirmó que la violación de esta chica la había impactado y asustado tremendamente, agregando lo siguiente: "I think all my work has been like that -a personal response to a situation [...] I can't see being theoretical about an issue like that" (Ana Mendieta 90). Más tarde dirá que realizó esta performance "as a reaction against the idea of violence against women" (Viso 256).

A diferencia de Mendieta, Barraza no recurre a una escena explícita pues, al estar inmersa en una realidad que está literalmente bañada en sangre -contraria al ambiente supuestamente "civilizado", "higiénico", de un campus universitario norteamericano-, lo que busca es representar a la violencia por medio de lo opuesto: sin la presencia evidente de la sangre. La salvadoreña, como se observará en las imágenes a continuación, recrea el cuerpo femenino, pero subvirtiendo la propuesta clásica de desnudo, el objetivizado, exotizado y sexualizado por la mirada masculina. Es decir, aquel desnudo por el que las Guerrilla Girls ${ }^{13}$ protestaron ante la falta de visibilidad de las mujeres artistas en los museos establecidos y que convirtieron en imagen icónica gracias a su famoso cartel: Do women have to be naked to get into the Met Museum? (1989). Si bien el "cuerpo

(2008) está acompañada de un texto que menciona a Mendieta: "La pieza inicia y termina con el sonido de chicharras al fondo marcando el tono en dirección a lo efímero de la vida y como símbolo cristiano de época de crucifixión y resurrección. El escenario es un espacio vacío pero confinado, casi monocromático, con iluminación natural en el que aparece la figura humana a contraluz, desenfocada a veces y a diferentes ritmos de tiempo desdoblándose continuamente. La pieza, según Barraza, asume el carácter de un ritual con evocaciones chamánicas, sufíes y budistas pero también con referencias artísticas de lo poético-mítico de artistas como Joseph Beuys y Ana Mendieta. Es la activación de un espacio social imaginario -en donde se convocan a todos los asesinados y a los espectadores- a través de un conjunto de acciones resumidas en el carácter de danza" (31).

${ }^{13}$ Las Guerrilla Girls es un grupo anónimo de artistas feministas que nació en Nueva York en 1985. Adquirieron fama debido a sus protestas frente a museos como el MoMA y a sus tácticas humorísticas plasmadas en carteles con contenidos irónicos y gráfica llamativa, los cuales tenían como objetivo denunciar el desequilibrio de género y la corrupción en el mundo del arte. Las artistas que formaron parte del grupo originario aparecían con máscara de gorila para ocultar su identidad.

$111 \frac{\text { Revista Iberoamericana, Vol. LXXXV, Núm. 268, Julio-Septiembre 2019, }}{11}$ IS29-759 
del delito" de Barraza alude al desmembramiento -el cuerpo desnudo en un pliego y la cabeza decapitada en otro pliego- provocando una tensión anímica, es el blanco que le rodea lo que más inquieta, un vacío que está a punto de borrar o devorar al cuerpo. $\mathrm{Si}$ en la oposición binaria tradicional, Naturaleza representa lo femenino (concretado en su cuerpo) y lo irracional (Pathos), y Cultura representa lo masculino, la Razón (Logos), ¿qué pasa cuando en una cultura se ha perdido el diálogo, se ha naturalizado la violencia y se ha traducido en polarización, exclusión, monstruosidad? Esa es la pregunta retórica que se mantiene planeando entre los cuerpos de estos dibujos.

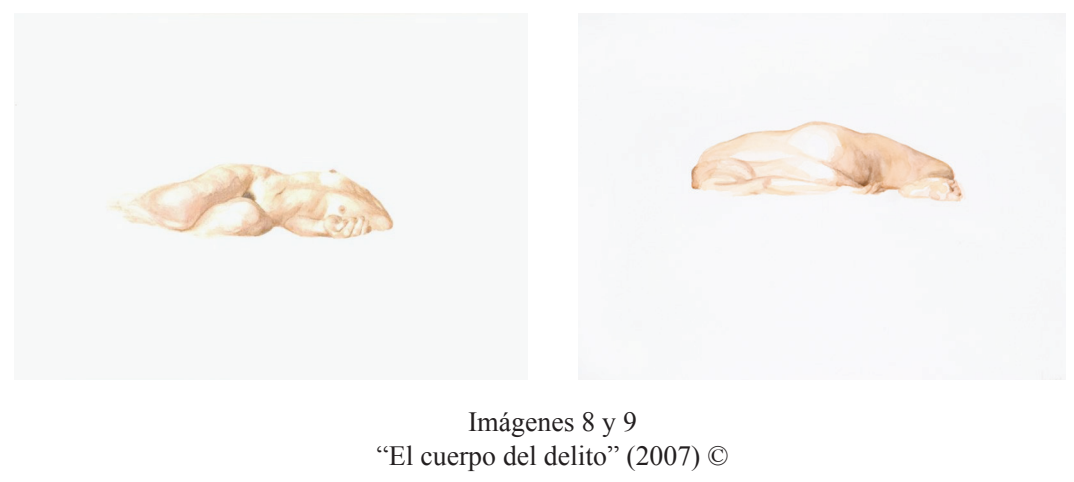

Esta serie de Barraza, en general, expresa una rebeldía contra el plano, es decir, los cuerpos de mujeres aparecen sin marcos de referencia, como suspendidos, sobre un fondo blanco; quizá representan la necesidad de contextualizar los cuerpos femeninos en un entorno alternativo, fuera de normativas de género y de las leyes inamovibles pero, sobre todo, fuera de la supuesta locura tradicionalmente adjudicada a lo femenino: aquí se quiere llamar la atención a que sus cuerpos han sido violentados por ser precisamente de mujer.
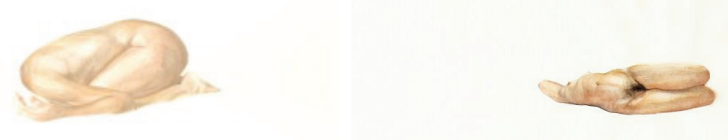
Estos cuerpos suspendidos provocan la impresión de que han sido lanzados al vacío, que se encuentran flotando en un espacio intermedio, marginal, al que no se puede seguir ignorando. Y también deducimos que su creadora nos está diciendo que, ante esa agresión cotidiana, solo son posibles dos opciones: dejarse estrellar ante la fallida refundación de la nación, los desvíos y desvaríos de su modernidad democrática; o aprender a reinventar y fundar espacios de supervivencia, alternativos, inclusivos, quizá el sueño de un diálogo sostenido.

La salvadoreña también nos demuestra su conocimiento del cuerpo humano-desde un punto de vista anatómico y estético- hasta el punto de transformarlo, deformarlo, dando cabida a una nueva propuesta conceptual del cuerpo femenino: aunque están desnudos, y alguno en una posición que podría parecer erótica, lo que sobresale, más bien, es que comunican una presencia a través de la ausencia de vida. Están presentes porque se manifiestan y participan hacia afuera, se materializan en un cuerpo, y es por medio de este que se disputa, como dije antes, la inscripción de las normativas de género y los estereotipos que lo predeterminan como "cuerpo de mujer", que en ese contexto de violencia, se hiperboliza como cosa simultáneamente deseable y desechable.

Por otro lado, tenemos las cabezas. En el díptico, acompañado de su cuerpo, hay una subversión del famoso cuadro de Gustave Coubert, El origen del mundo (1866): aquí la mujer desnuda no aparece entre sábanas con el rostro escondido, porque aquí su cabeza aparece separada:
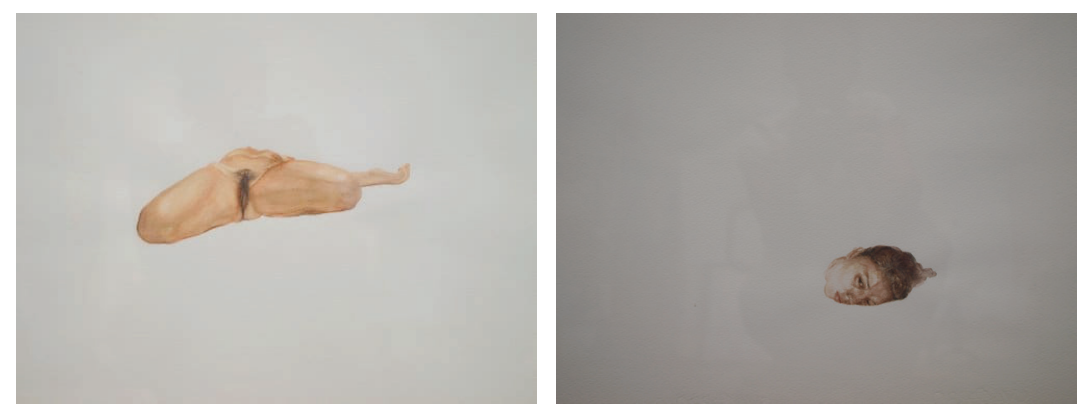

Imágenes 12 y 13

“El cuerpo del delito”, Díptico (2007) C

En esas cabezas, aparece el rostro de Barraza, es decir, es ella misma deformada, sin cuerpo, su cabeza rodante. Al respecto, la artista hace una diferenciación entre su autorrepresentación y la representación de los otros, los ausentes:

En las series "El sueño de la razón", "El cuerpo del delito" y "Cabeza rodante", esa soy yo definitivamente, tanto cabeza como cuerpo. Son autorretratos. La parte que pasa

$111 \frac{\text { Revista Iberoamericana, Vol. LXXXV, Núm. 268, Julio-Septiembre 2019, }}{1129-759}$ 
por mis vivencias, en torno a ese contexto de violencia cotidiana tan desgarradora que atestigüé en ese momento. Esa violencia se vive a diario, pero en el momento en que se decide ser un testigo de lo que sucede, se le tiene que dar voz a ese testimonio, se es forma. Aunque yo sigo viviendo esa violencia, todos la vivimos, en esa serie asumí la responsabilidad de ser testigo y dar testimonio. Eran en gran medida autobiográficos, existenciales, en relación con el entorno en que yo vivía en ese momento. Sin embargo, todas las demás piezas [y las otras series que conforman a República de la Muerte] se vuelcan hacia el otro, la mirada hacia el otro: el retrato que hice de Katia Miranda [niña violada y asesinada] o la pieza que se llama "El libro de los muertos", que son retratos de setenta víctimas de la violencia reportadas en los periódicos. La mirada al otro -el otro asesinado- no es el otro que acompaña, sino el otro que ya no está, que está ausente, que ha sido violentado, que ha sido agredido, eliminado de tu entorno. La intención era traerles nuevamente, recuperarles, darles vida, darles un espacio digno de remembranza y la posibilidad de jugar un rol determinante en el discurso colectivo. ("Entrevista" $\mathrm{s} / \mathrm{p}$; cursivas personales)

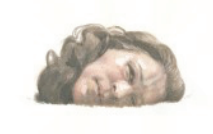

Imagen 14

"El cuerpo del delito" (2007) (C)

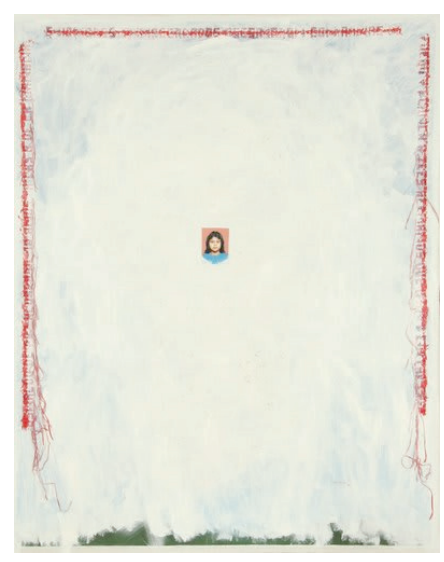

Imagen 15

Homenaje a Katia Miranda (2008) (C)

Aceite, acrílico e hilo de seda sobre tela, 230 x $180 \mathrm{~cm}$. 
Al observar las piezas de "El cuerpo del delito", "El sueño de la razón” y "Cabeza rodante" desde la perspectiva de la autorrepresentación, resulta inevitable no ver en ese rostro a la figura autorizada que Barraza representa en el campo cultural: mujer, madre, artista de amplio reconocimiento, gestora y activista. Todas estas vertientes biográficas se funden en ese rostro, en esa cabeza aparentemente cercenada. Y digo aparentemente porque las expresiones de su rostro también están comunicando otras lecturas. En ocasiones tiene aire melancólico pero reflexivo; en otras, desafiante. La cabeza: lugar donde se desarrollan las acciones del pensamiento, la riqueza de la imaginación, el juego de la creatividad, la suspicacia del intelecto. Es la combinación de todo esto lo que prefigura su papel autorial y hace que percibamos a alguien consciente de su sitio, su posición, en ese contexto particular. Las cabezas se han colocado separadas del cuerpo quizá también para que la atención del espectador no se distraiga observando la belleza tradicional atribuida al cuerpo femenino, sino que se concentre en la inteligencia que emana de esa mirada, una que mira de frente, estableciendo un juego de ajedrez con nosotros/as, un juego balanceado, de igual a igual.

Por otra parte, el papel de autora de Mayra Barraza, al parecer, nos dice que su dolor desgarrado, su intimidad, se ha fundido con lo femenino plural: ella se considera parte del conjunto, se identifica con este. Así, bajo esa concienciación se lee: yo soy todas, todas soy yo. Es como si le dijera a su interlocutor cultural: sí, es cierto, estoy aquí, con todo ese dolor, el de ellas, pero aún no estoy muerta, porque debajo, en mi interior, estoy yo, la autora legitimada que seguirá pintándolas, recreándolas. Su figura se alza, pues, como la autora que, por medio de su trayectoria artística, irrumpe e interrumpe tanto el curso naturalizado de la violencia como los discursos que se despliegan a partir de esta.

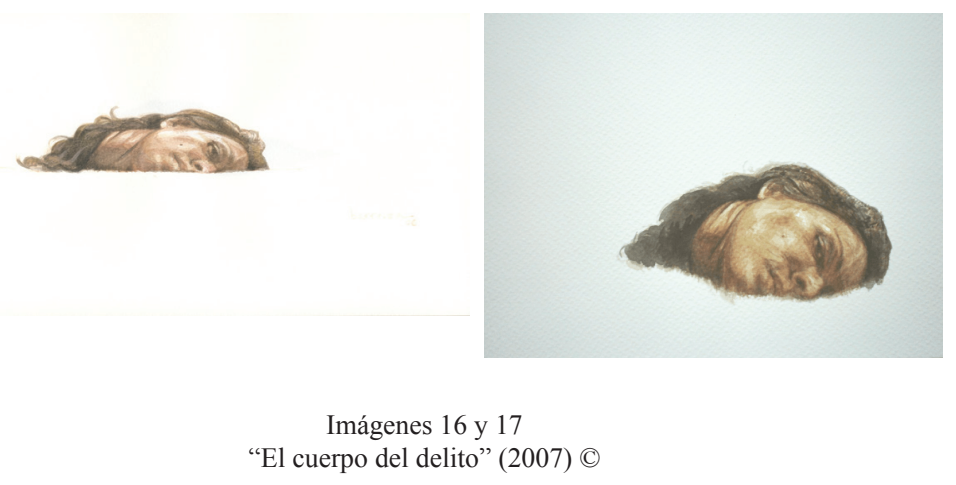

$111 \frac{\text { Revista Iberoamericana, Vol. LXXXV, Núm. 268, Julio-Septiembre 2019, }}{1129-759}$ 


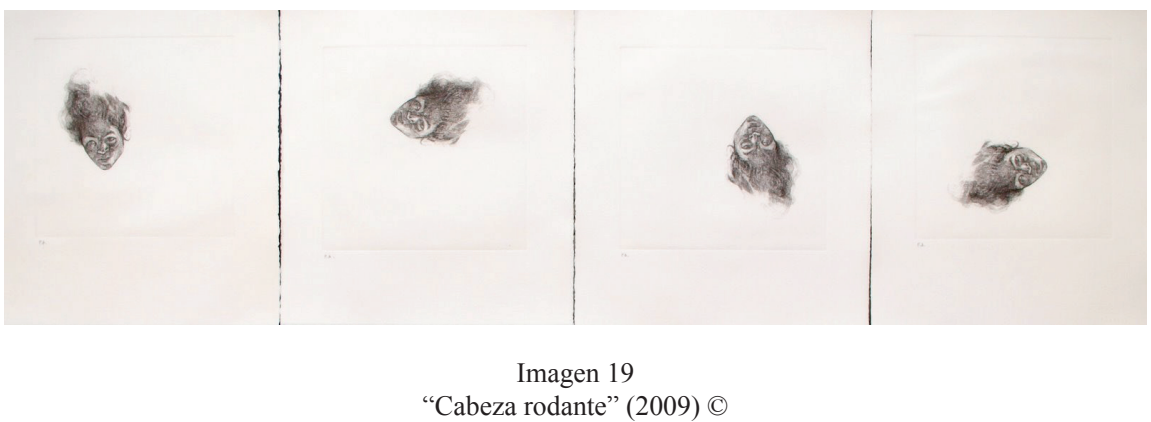

Por último, en "Planta", aparece la cabeza de Barraza, ya con los ojos cerrados, pero con el tronco de un izote naciendo de su boca. Este dibujo viene a ser la culminación del proceso de autorrepresentación. La expresión de su inconformidad con la realidad de "afuera" (donde cabe lo personal, lo social y político) se concreta en la posibilidad de convertirse en una planta de izote, considerada la flor nacional de su país. Así, se establece un diálogo con el emblemático diario de Carlos Henríquez Consalvi, conocido como "Santiago": guerrillero venezolano establecido en El Salvador, fundador de Radio Venceremos durante la guerra civil, actual director del Museo de la Palabra y la Imagen (MUPI), y también uno de los gestores culturales más activos en ese país. Su diario se titula La terquedad del izote (1992) y tiene un epígrafe que dice así: "Izote. Flor nacional de El Salvador, blanca y olorosa, de hojas fuertes y punzantes, que renace de su propio tronco herido [...] que nunca muere. Es la Terquedad del Izote" (s/p). Así, pareciera que en "Planta", Barraza apelara a un acto de comunión con una verdadera movilización social, no entrampada en los códigos de las actuales élites políticas ni en la naturalización de la violencia. Se trata, pues, nuevamente, de un yo que se coloca en lo colectivo y se esmera por no ser una corporalidad tópica sobre la que actúan lineamientos políticos que le reprimen, sino un yo que se volverá 
materia nueva, cuerpo nuevo, quizá en un ámbito más justo, más allá de las nociones tradicionales y patriarcales de lo "nacional" - no es gratuito que el dibujo se llame únicamente "planta", sin referir a una distinción de la flor nacional-.

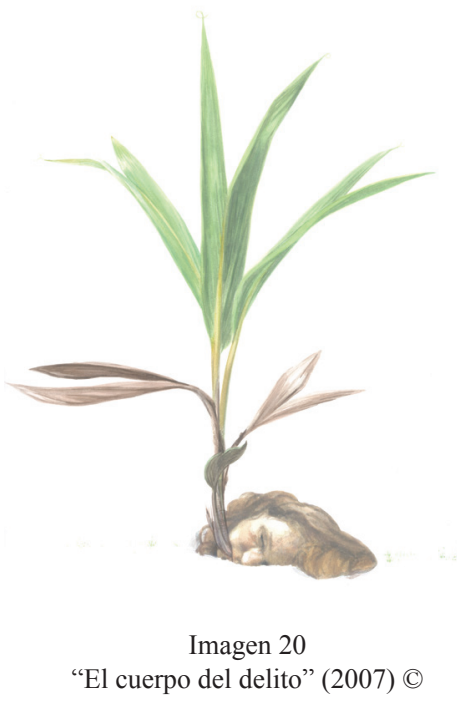

Es así como Barraza plantea que los espacios imaginados se convierten en el punto de partida desde donde pueden surgir nuevas propuestas de subjetividad y colectividad. Estos espacios, por lo tanto, dejan de ser solamente utópicos y se convierten también en espacios habitables de superviviencia. Esta es, a mi parecer, la propuesta artística y autorial que ha creado Barraza y, para observarla mejor, cito sus palabras aparecidas en una de las entradas del blog 100 días en la República de la Muerte:

\section{2 noviembre 2006}

Aquí incluyo unos poemas de Wislawa Szymborska, ${ }^{14}$ poeta polaca, que me enviaron hace poco. ¿De qué servirán? Una pregunta que he recibido respecto a este blog en varias ocasiones. ¿Quién sabe? Hay cosas que no se pueden medir, ni cuantificar y no por ello deben dejar de existir, y no por ello son inútiles. Pienso en esas pequeñas semillitas voladoras que se dispersan en el aire. Más de alguna caerá en suelo fértil y algo crecerá. (100 dias Blog s/p)

14 Los poemas de Wislawa Szymborska que se transcriben en el blog son "Fin y principio" y "Monólogo para Casandra" (Barraza, 100 dias Blog s.p.).

$111 \frac{\text { Revista Iberoamericana, Vol. LXXXV, Núm. 268, Julio-Septiembre 2019, }}{1129-759}$ 
Aquella concepción de lo femenino plasmada en la serie Feral Female, como algo no domesticado por los estándares convencionales, se funde aquí en una reflexión sobre la nación y su posible regeneración. Barraza propone, desde su figura de autoraciudadana, que en dicha regeneración histórica, en esa "terquedad del izote", las mujeres deben continuar participando activamente, no desfallecer. ${ }^{15}$ Siguiendo el poema de Szymborska, "Principio y fin" (1993), y citado en el blog, el arduo trabajo de la reparación material y afectiva de una nación ultrajada, se debe hacer en comunidad: "Después de cada guerra / alguien tiene que limpiar. / No se van a ordenar solas las cosas, /digo yo / . . / Alguien debe meterse / entre el barro, las cenizas, / los muelles de los sofás, / las astillas de cristal / y los trapos sangrientos" (s/p). El cuaderno que elaboró Mayra Barraza -hoy en día testimonio de un debate enriquecedor, esbozo de memoria, cuerpo textual donde se entrelazan lo colectivo y lo individual, en ocasiones con tonos intimistas y, en otras, con acento ciudadano - evidencia el perfil de una autora que se asume no solo como ciudadana, sino que también como arquitecta de comunidad. Una imagen de autora que encarna ideales nuevos de la nación, esta vez liderados por lo femenino, vuelta de tuerca al imaginario que elogia a los Eneas, al héroe masculino, el hacedor de conquistas; mujer artista que desentraña, desgrana, y se afana en comprender el alma nacional. Obra-espejo, aparentemente en singular, pero en realidad hilvanada por los hilos de un caleidoscopio.

\section{BiBLIOGRAFÍA}

Aira, César. Alejandra Pizarnik. Barcelona: Omega, 2001.

Agüero, Arnulfo. "Mayra Barraza y el grito de la soledad". La Prensa, 8 oct. 2014: 6B. Albán, Jorge. Ardides ante el espectáculo en América Central. Curaduría para Interactiva 07. Documento facilitado por Mayra Barraza.

Ana Mendieta. Santiago de Compostela, Barcelona: Centro Galego de Arte Contemporánea / Fundació Antoni Tàpies, 1996. [Catálogo].

Barraza, Mayra. "100 días en la República de la Muerte”. Documento facilitado por la artista.

100 días en la República de la Muerte. Blog. 01 sep. 2006 al 10 dic. 2006. $<$ http://repblicadelamuerte.blogspot.com.es>. 12 sept. 2017.

${ }^{15}$ En El Salvador, ya las mujeres revolucionarias se han referido a las prácticas sexistas y jerárquicas dentro del movimiento, así como a los costos emocionales de la guerra y los experimentados en el período de posguerra: dolores en el cuerpo (taquicardias, úlceras, desvanecimientos), angustias y depresiones. Además, "las mujeres obtuvieron un extra de frustración porque los Acuerdos [de Paz] fueron escritos totalmente en masculino (literal y simbólicamente hablando), a pesar de la presencia de más de una mujer en las comisiones negociadoras y firmantes de los mismos" (Vázquez, Ibáñez y Murguialday 51).

$111 \frac{\text { Revista Iberoamericana, Vol. LXXXV, Núm. 268, Julio-Septiembre 2019, }}{1129-759}$ 
"Entrevista personal". San Salvador-Barcelona, 30 ago. 2017.

República de la Muerte. Tegucigalpa: Centro Cultural de España de Honduras y la Agencia Española de Cooperación Internacional para el Desarrollo (AECID), 2010. [Catálogo].

“Acielo abierto". A cielo abierto. Construcciones espacio-temporales de género. San Salvador: Organización de las Naciones Unidas en El Salvador, Secretaría de Cultura de la Presidencia, 2016. 11-13.

Barthes, Roland. Prétexte: Roland Barthes. Colloque de Cerisy. París: Union Génerale d'Editions, 1978.

Castellanos Moya, Horacio. “La apuesta de Mayra”. República de la Muerte. Tegucigalpa: Centro Cultural de España de Honduras y la Agencia Española de Cooperación Internacional para el Desarrollo (AECID), 2010. 5-6 [Catálogo].

Breves palabras impúdicas. Un ensayo y cuatro conferencias. San Salvador: Centro Cultural de España/Colección Revuelta, 2010.

Cróquer, Eleonora. Escrito con rouge. Delmira Agustini (1886-1914), artefacto cultural. Rosario: Beatriz Viterbo, 2009.

"Casos de autor: anormales/originales de la literatura y el arte"(II). Allí donde la vida (es obra)". Voz y escritura. Revista de estudios literarios n. 20 (2012): 89-103.

Galindo, Evelyn. "La producción cultural contra hegemónica: República de la Muerte de Mayra Barraza”. Legacies of War in El Salvador. Blog de Evelyn Galindo. 11 jul. 2015. <http://postwarelsalvador.blogspot.com.es/2015/07/la-produccioncultural-contra.html>. 6 nov. 2017.

Henríquez Consalvi, Carlos. La terquedad del izote. La historia de Radio Venceremos. México, D.F: Diana, 1992.

Huezo Mixco, Miguel. La perversión de la cultura. San Salvador: Ediciones Arcoiris, 1999.

"El arte y la literatura en el país de los ciegos". Documento facilitado por la artista.

Lacayo Deshon, Ramiro. "Siempre que puedo retorno a los clásicos'. Entrevista a Mayra Barraza”. Carátula 44 (oct.-nov. 2011). <http://caratula.net/ediciones/44/ arte-mbarraza.php>. 4 sept. 2017.

"Mayra Barraza". Liliana Bloch Gallery. <https://lilianablochgallery.com/mayrabarraza>. 30 ago. 2017.

Myra Barraza. <http://mayrabarraza.com/>. 3 nov. 2017.

Man, Paul de. "La autobiografía como desfiguración". Anthopos. Boletín de información y documentación 29 (1991): 113-118.

Manchester, Elizabeth. “Ana Mendieta”. Tate. 2009. < http://tate.org.uk/art/artworks/ mendieta-untitled-rape-scene-t13355>. 4 nov. 2017.

Meizoz, Jérôme. “¿Qué entendemos por 'postura’?”. Los papeles del autor/a. Marcos teóricos sobre la autoría literaria. Eds. Aina Pérez Fontdevila y Meri Torras Francés. Madrid: Arco Libros, 2016. 187-204.

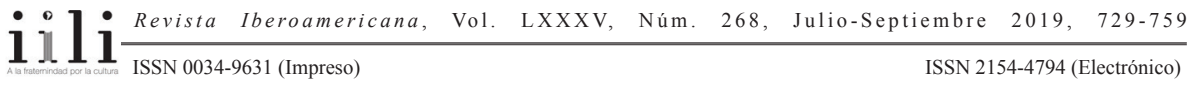


“Observatorio de Violencia de género contra las mujeres”. ORMUSA (Organización de Mujeres Salvadoreñas por la Paz). <http://observatoriodeviolencia.ormusa. org/>. 20 ago. 2017.

Paz, Octavio. Sor Juana Inés de la Cruz o Las trampas de la fe. Barcelona: Seix Barral, 1998.

Pérez Fontdevila, Aina y Meri Torras Francès. "Introducción: Hacia una biografía del concepto de autor". Los papeles del autor/a. Marcos teóricos sobre la autoría literaria. Eds. Aina Pérez Fontdevila y Meri Torras Francés. Madrid: Arco Libros, 2016. 11-51.

Pérez Fontdevila, Aina, Meri Torras Francès y Eleonora Cróquer. "Ninguna voz es transparente. Autorías de mujeres para un corpus visibilizador". "Autoría y género" (dossier). Eds. Aina Pérez Fontdevila, Meri Torras Francés y Eleonora Cróquer. Mundo nuevo. Revista latinoamericana VII 16 (ene.-jun. 2015): 15-27.

Pizarnik, Alejandra. Poesía completa. Barcelona: Lumen, 2001.

Pleitez Vela, Tania. "Dos lecturas del aislamiento. Lo sobrenatural y lo fantástico en Horacio Castellanos Moya y Claudia Hernández". "Estudios críticos sobre narrativa centroamericana 1990-2015" (dossier). Ed. Alexandra Ortiz Wallner. Boletín 69 (jun. 2016). Asociación para el Fomento de los Estudios Históricos en Centroamérica (AFEHC). < http://afehc-historia-centroamericana.org/index. php?action=fi_aff\&id=4285>. 1 sept. 2017.

Literatura. Análisis de situación de la expresión artística en El Salvador. San Salvador: Fundación AccesArte, 2012.

Ramírez, Sergio. "El niño, el buitre y el cerdo". Página 12, 19 sept. 2006. <https:// pagina12.com.ar/diario/contratapa/13-73203-2006-09-19.html>. 3 nov. 2017.

Rey Rosa, Rodrigo. "Lapidario". República de la Muerte. Tegucigalpa: Centro Cultural de España de Honduras y la Agencia Española de Cooperación Internacional para el Desarrollo (AECID), 2010: 48 [Catálogo].

Rodríguez Gutiérrez, Milena. Lo que en verso he sentido: La poesía feminista de Alfonsina Storni (1916-1925). Granada: Universidad de Granada, 2007.

Sevilla Bolaños, Letzira. "Trazos salvadoreños en Galería Códice”. El Nuevo Diario, 8 oct. 2014 . $<$ http://elnuevodiario.com.ni/variedades/331788-trazos-salvadorenosgaleria-codice/>. 28 oct. 2017.

Valencia, Roberto. "El Salvador es un charco de sangre" (Crónicas Guanacas). Los Blogs de El Faro, 5 ene. 2016. <http://losblogs.elfaro.net/cronicasguanacas/2016/01/ el-salvador-es-un-charco-de-sangre.html>. 5 sept. 2017.

Viso, Olga M. Ana Mendieta: Earth Body, Sculpture and Performance 1972-1985. Washington D.C.: Hirshhorn Museum and Sculpture Garden, Smithsonian Institution, 2004. [Catálogo].

Vázquez, Norma, Cristina Ibáñez y Clara Murguialday. Mujeres montaña. Vivencias de guerrilleras y colaboradoras del FMLN. Madrid: horas y HORAS, 1996.

$111 \frac{\text { Revista Iberoamericana, Vol. LXXXV, Núm. 268, Julio-Septiembre 2019, }}{1129-759}$ 
Palabras clave: autoría, postura, violencia, memoria

Recibido: diciembre 2017

Aprobado: diciembre 2018 
